\title{
Hyperreality in Surat Cinta Untuk Kartini’s Film
}

\author{
Asri Bariqoh \\ Universitas Negeri Surabaya \\ STKIP-PGRI Sampang \\ Surabaya, Indonesia \\ asribariqoh@mhs.unesa.ac.id
}

\author{
Setya Yuwana Sudikan \\ Universitas Negeri Surabaya \\ Surabaya, Indonesia \\ setya.yuwana@unesa.ac.id
}

\author{
Endang Surachni \\ Universitas Negeri Surabaya \\ Surabaya, Indonesia
}

\begin{abstract}
Film is the most perfect simulation and hyperreality media. Through the film, reality of the past was presented by aligning between reality and illusion and fantasy. This study aims at determining the hyperreality in the film Surat Cinta untuk Kartini. Theoretically, this study is a contribution to the development of literature, especially those related to postmodernism theory. Practically, this study can be used as a reference for similar research. This study uses a sequential and detailed analysis, resulting in accurate and reliable research. Based on the discussion, it draws a line that hyperreality is presented through the representation of fantasy about Kartini and the postman. Such hyperreality is presented by the actor's similarity to Rangga and Sarmadi figures, a simulation of past reality, and the use of language in communication. Based on the discussion, it was concluded that Surat Cinta untuk Kartini used hyperreality in addition to the historical reality.
\end{abstract}

Keywords—hyperreality, reality simulation, fantasy

\section{INTRODUCTION}

The conflicting position between men and women has continually raised an endless problem these days. This problem also arises in Indonesia where native or Javanese women had previously owned limited space to move. One reason is the lack of access to education as part of tradition that restricts women to have activities outside. The regulation banned women to leave home and gain education [1]. In addition, the absence of special schools of indigenous women also became a barrier for women to move forward. But all these issues were distangled since Kartini's involvement in education that provided access for women to education. She is known as a female reformer who lived in the 19th century, a Javanese woman who was open minded and had advanced thinking. Seeing the suffering of his people, she then takes further step by establishing a female school.

This past reality attracted the attention of filmmakers which are manifested through the touch of simulated reality in the film. To these days, there have been three films depicting life journey of Kartini. One of the three films is a Surat Cinta untuk Kartini. Although this film tells the life journey of Kartini and the fate of women in old days, but the film takes a simulation of story from different point of views. The plot focused on the simulation of Kartini's life and a postman who sends and delivers Kartini's letters.

According to Baudrillard [2], simulation cannot be considered equal with reality because the simulation is different from representation. This means that if the representation describes the similarity between the sign and reality, then the meaning of the simulation is the opposite. Baudrillard [2] provides a simulated example with a simulated person who becomes a thief. When someone comes to the store and pretends to be a thief, how will he tell you that this is just a simulation? Yet all his movements are the same as a real thief. So the response perceived by people who pretend to be the same thief as a thief in the event of theft in general.

The media thus does not represent reality. Media produces by itself. This is as revealed by Baudrillard [2] that in the world of simulation is not a reality that mirrors reality, but models. Therefore, the simulation is a process whereby the representation of an object precisely replaces the object itself, where the representation becomes more important than the object.

For Baudrillard [3] now all the real is a simulation. This simulation is accelerated with the presence of film media Reality at present presupposes a redefinition of everything that is possible and can be perfectly reproduced, meaning it can be. Social reality is taken over by the reality of media that claims itself as a social reality and represents the social model itself [4].

Reality in multimedia especially Surat Cinta untuk Kartini can become a second reality, in addition to the real reality that has been known through history. Its existence as a nationwide film can have an effect on the substitution of true reality, since the simulation is a process of realizing reality to be simulacra as an inferior form of representation of unknown origin [5] This understanding is reinforced by the opinion of Vaughan which describes the film as a dream factory that presents a fictitious reality complete with stories and characters as well as arrangement of the background [6] Through the production process makes the simulated reality in the movie lose touch with the reality that it represents. 
The simulated reality in the film captures perfect simulation of hyperreality and presents factual reality to the audiences. Hyperreality blends conflicting concepts such as reality and illusion, fact and fantasy, which can be presented in the form of realistic or real fantasy or fantasy representations [7]. The concept of hyperreality can be looked upon different timelines in history.

Based on the above explanation, the simulated reality in Surat Cinta untuk Kartini can replace the original reality as this is regarded as true reality, replacing the original one. This condition is called hyperreality which can be identified as a real reality beyond its original reality. The audience can no longer distinguish between real and fake. In other words, hyperreality creates a condition, in which falsity mingles with authenticity, the past mingles with the present, the facts mingle with fabrication, melt into reality, lie to unite with truth. The categories of truth, falsehood, authenticity, issues, secular reality-will no longer apply [8].

The world of hyperreality not only reproduces the lost reality, but also the unreal world such as fantasy, dream, illusion, hallucination or science fiction. Baudrillard exemplifies hyperreality through wax museums or artificial museums of artwork and ghost towns. The wax museum is the reproduction of historical realities, such as the Monalisa, Marilyn Monroe, the Tower of Pisa and others, while the ghost town is a reproduction of fantasy, dream, illusion or science fiction like Donald Duck, Cinderella, Batman, Superman, and Terminator.

The existence of this hyperreality can ultimately change one's understanding of reality. This is influenced by the ability of technology to reproduce reality so that it can no longer be distinguished between the real reality and the reality of production. Baudrillard states that hypnosis causes one's understanding of the real historical reality to be further away because it is replaced with that reality [9].

A fantasy-represented hyperreality can be found in Kiaei's study which discusses about the hyperreality in the film of The Lovely Bones [10]. The finding of study reveals the representation of hyperreality through Alice's imagination of heaven. She describes heaven as an environment or garden that can be known in the world. The portrayal of heaven depicts hyperreality as religion also explains the existence of heaven, although the reality of fantasy has no basis of the true paradise.

The film Surat Cinta untuk Kartini also portrays hyperreality that was introduced with fantasy of past reality. The hyperreality of fantasy is portrayed by characters who live in the present that explores their fantasy about the lives of Kartini and the Postman. The setting takes place in the present days and portrays the learning situation background at school. Through the learning process, the simulated reality of Kartini is created.

What history said about the biography of Kartini had never mentioned the existence of the postman, which was later portrayed in the film that takes point of the view of the postman. The film Surat Cinta untuk Kartini takes another point of view that apart from what commonly told about
Kartini. In addition, the representation of hyperreality in the movie directed by Azhar Kinoi Lubis is identified through a statement that the movie is merely a a fiction, instead of a biopic film. This confession strengthens the existence of hyperreality in the simulated reality of the film which is presented through plot, narrative, and language.

\section{METHODS}

The object of research in this study is the film Surat Cinta untuk Kartini. The film is transcribed and then the data is obtained based on transcription results. The data is obtained by reading the film in depth and dividing the transcription of the film in sequences. This classification is arranged to make accurate and reliable data. Through this subdivision technique, the data describing the hyperreality are grouped according to the study. The analysis is made by grouping the types of hyperreality and putting them in sequence and detail [11]. Through a series of analysis, the unity of the story in the film can be traced down. Furthermore, the analysis and discussion are arranged in detail, so that it is clearly known in the simulation reality of Surat Cinta untuk Kartini's film.

\section{HYPERREALITY IN SURAT CINTA UNTUK KARTINI'S FILM}

The reality simulation of Surat Cinta untuk Kartini's film begins with presenting the reality of learning in school. This simulation is seen through the screams of the students in the classroom as the teacher begins learning history. Then the simulation of reality becomes hyperreality through sequences when Rangga's teacher tells about the postman. The simulation of present reality turns into a simulation of past reality. This reality simulation is the imagination of the students and teachers in the film. The imaginary representation of the simulation signifies a hyper-reality, the simulated world of imagination. This hyperreality is related to the use of flashback techniques in storytelling. However, the flashback used is not a dream or activity of remembering past events that occur on the character, but an imagination about events that occurred during the Kartini's storytelling. This reality is the second reality in addition to the real reality. Such hyperreality is further reinforced by the reality of the imagination as the new reality being offered can be enjoyed together, not just individuals. Eventhough as imagination, that could be vary for each individuals.

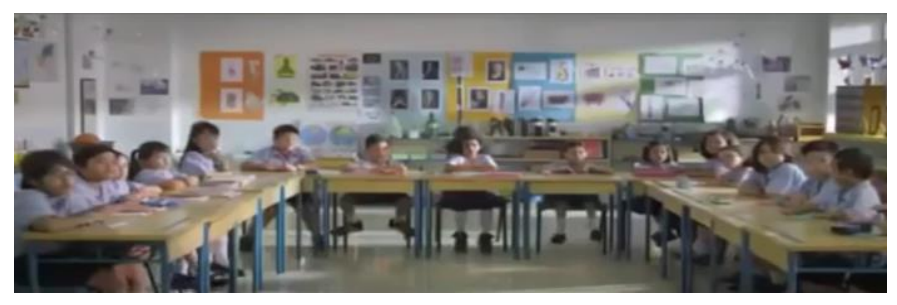

Fig.1. (the situation of learning history in classroom) 


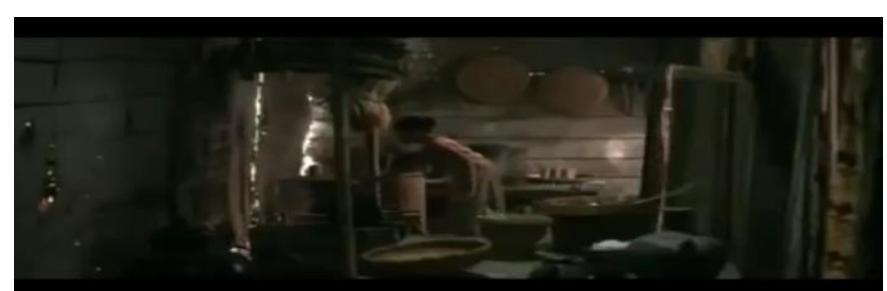

Fig. 2. (students imagination about the history of kartini's life)

The reality of the Surat Cinta untuk Kartini is not only presented in storytelling, but also in the elements of story such as characters, background and simulated events. One of the main characters of the film is Sarmadi, a postman who delivered and sent letters. Hipereality performed by the figure of teacher Rangga and Sarmadi is played by the same person even though the setting backgrounds are different. Both figures are played by Chiko Jericko, an Indonesian actor. Master Rangga who lives in the present is the one who delivers the imagination of the postman (Sarmadi) who lived in the 19th century. Both figures played by the same actor basically shows the hyperreality of the film.

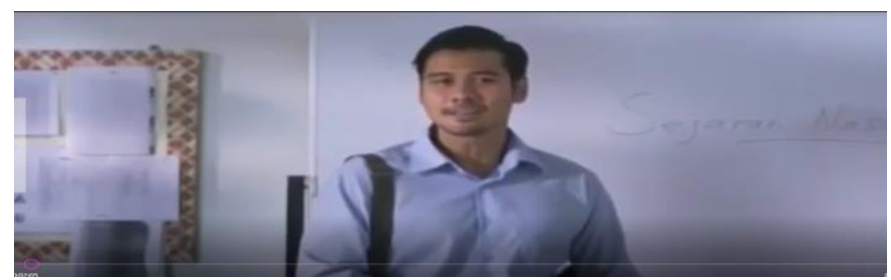

Fig. 3. (present, Mr. Rangga as one of the teacher in the classroom)

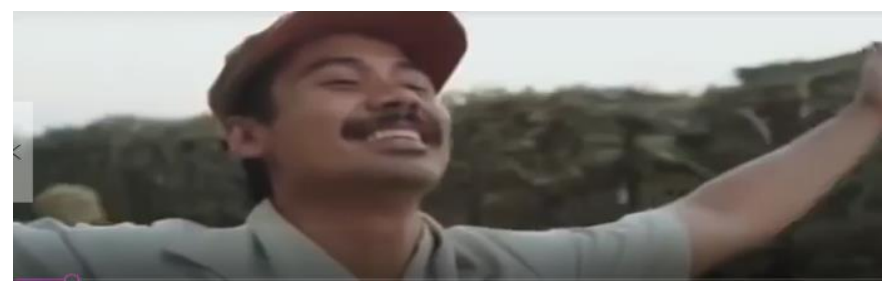

Fig. 4. (past (19 $19^{\text {th }}$ century), postman in student imagination)

Furthermore, the background on the film is also a hyperreality. It is found on the figure of the husband and wife of Dutch descent who use traditional clothing of Java. They look like two nobles, but their faces and white skin cannot be hidden. The scene was shot when Sarmadi delivered his first letter to a house, where a husband and wife sitting on the terrace of his house after receiving a letter from Sarmadi. Cultural acculturation that occurred in the scene obscures the background of the film as a film with the background of Dutch colonialism. The Dutch have a different way of dressing with the Javanese community. They wear dresses, while men wear shirts, coats and pants. In addition, the Dutch considered the natives as dirty and uneducated. So that cultural acculturation is not possible at that time. So, the simulation of reality in the scene is categorized as a hyperreality.
In addition to the use of characters and backgrounds, the hyperreality can also be found in the school founded by Kartini and her two siblings, which is located on the banks of the river. Scene describes Kartini is awaiting for her native students. The selection of the riverside setting is a hyperreality because in the past Javanese women, especially the nobles, cannot freely leave their home environment. This is because patriarchal culture is still very strong. When I reached the age of twelve, I stayed home. I have to go to the box. This fact is as revealed by Kartini that he was confined and cut off all communication from the outside world [1]. In addition, in the biography of Kartini mentioned the school was established in the neighborhood of duchy, in the neighborhood of his house. The use of this background clearly offers a different reality than the real reality. Such reality can replace real reality.

Furthermore, hyperreality can also be found in the simulation of reality events in the film. This hybridity occurs in events related to the postman. The postman who delivered the letter to Kartini is described as having an awareness of the importance of education for women. So he asked specifically for Kartini to want to teach her son named Ningrum. This scene is a hyperreality, since the native men of the past have not considered education for women important. The presence of the Sarmadi figure who asked Kartini to teach his son provides an alternative simulation of reality that is different from history. He became a native man who cared about the fate of women.

In addition, Sarmadi figure became one of the figures that accompany the life of Kartini. He fell in love with the figure of Kartini, so when Kartini proposed he felt a broken heart. He fell ill and did not have the spirit of life. This reality simulation shows the deep affection of a native man to the women of the nobility. This love story is increasingly visible with both meetings on several occasions.

Hyperreality also found through the use of language. Film Surat Cinta untuk Kartini is set back in the 19th century, when the Indonesian language has not been an official language of unity. Even the background occurred several years before the first spelling in Indonesian was made. This historical reality shows the language used in those days is the local language, Malay language, and Dutch language. Similarly, the language used in the film. But the movies are not using $100 \%$ using Java language when simulation of past reality is told. In some scenes, this are still used in communication. The use of this Indonesian language can be understood as a move aimed at providing understanding to the audience. But it made history uprooted from its time and made it a hyperreality. The audience enjoyed the story in the film and forgot the film as a 19 th century film.

\section{CONCLUSION}

Hyperreality in the film Letters to Kartini represent fantasy representation about the reality of the past. Hypereignity is characterized by changing the present-day background to the past, followed by the embodiment of the fantasy of the students and the two teachers who are in class. Fantasy representation begins with the similarity of characters, namely between teacher Rangga and Sarmadi, a figure who lived in 
the Kartini. In addition, the reality of simulating reality is also the reality of past women who are described as having the freedom to be in the public sphere, as well as the language used by Kartini. The use of Indonesian language in communication between Kartini and Mr. Abendanon makes the audience understand what is being discussed. But this simulation reality is a hyperreality, because history teaches Kartini capable and intelligent use of Dutch language. So the representation of fantasy in the film Letters for Kartini can be a second representation in addition to its factual reality.

\section{ACKNOWLEDGMENT}

This work would not have been possible without the scholarship or financial support from Directorate General of Higher Education Ministry of Research and Technology as the organizer of BPPDN.

\section{REFERENCES}

[1] H. Geertz (ed). Letters of a Javanese Princess: Raden Adjeng Kartini. Transl. Agnes Louise Symmers. New York: Norton Company, 1964.

[2] J. Baudrillard. Simulacra and Simulations in Literary Theories: a reader \& guide (ed. Julian Wolfreys). New York: New York University Press, 1999.

[3] J. Baudrillard. Simulations. New York: Semiotext(e), 1983.

[4] Y. A. Piliang. Hipersemiotika: Tafsir Cultural Studies atas Matinya Makna. Yogyakarta: Jalasutra, 2003.

[5] R. W. Wolny. "Hyperreality and simulacrum: Jean Baudrillard and European postmodernism, European Journal of Interdisciplinary Studies, $8^{\text {th }}$, vol.1, 2017, pp. 76-80.

[6] M. H. Vaughan. "The paradox of film: an industry of sex, a form of seduction (on Jean Baudrillard's Seduction and the cinema), Journal Film-Philosophy, 2010, pp. 41-61.

[7] G. G. Devi. "The concept of hyperrealism in cyberpunk films. The film the Matrix (1999): a case study," The $11^{\text {th }}$ International Confernce of ISSEI, pp.1-10, July-August 2008.

[8] Y. A. Piliang. Dunia yang dilipat: tamasya melampau batas-batas kebudayaan. Yogyakarta: Jalasutra, 2011.

[9] G. Coulter. Jean Baudrillard and cinema: the problems of technology, realism and history, Film-Philosophy Journal, 2010, pp. 6-20.

[10] S. Kiaei, and M. Safdari. "Hyper-reality in Sebold's the Lovely Bones, International Journal of Comparative Literature \& Translation Studies, 2014, pp. 53-58.

[11] Titscher, Stefan dkk. Metode Analisis Teks dan Wacana. Transl. Gazali, et al. Yogyakarta: Pustaka Pelajar, 2009. 